\title{
Dasar Pembagian Kewenangan Notaris Dan Pejabat Pembuat Akta Tanah (PPAT) Dalam Bidang Pertanahan
}

\author{
I Wayan Eka Darma Putra, Prija Djatmika, Nurini Aprilianda \\ Kantor Notaris Dewa Putu Dipta Dadia Nugraha \\ ekadarma03@yahoo.co.id
}

\begin{abstract}
This study aims to analyze the basis for authority division of notary and Official Certifer of Title Deed in land sector and to examine whether Article 15 Paragraph 2 letter (f) of Law Number 2 year 2014 is contrary to Article 2 of Government Regulation Number 37 year 1998 on the rule of position for Official Certifer of Title Deed. This research is legal research normative by design with statute and historical approaches employed. The legal materials obtained were analized to reveal the correlation between them. The results show that the authority of the notary comes from Notary Regulation (Stb. $1860: 3$ ) and the authority of the Official Certifer of Title Deed is generated from Government Regulation number 37 year 1998 on the rule of position for Official Certifer of Title Deed. Article 15 paragraph (2) letter (f) about notary position does not contradict Article 2 of Government Regulation number 37 year 1998 because the land deed such as lease deed, sale and purchase agreement, deed of land right release, the authority to sell, statement of inheritance, will, and deed of grant of mortgage is the authority of the notary and not the Official Certifer of Title Deed.
\end{abstract}

\section{Keywords : Notary, Land Deed, Official Certifer of Title Deed.}

\begin{abstract}
Abstrak
Penelitian ini bertujuan menganalisis mengenai dasar pembagian kewenangan Notaris dan Pejabat Pembuat Akta Tanah (PPAT) di dalam bidang pertanahan dan apakah Pasal 15 Ayat 2 Huruf (f) Undang-Undang Nomor 2 Tahun 2014 tentang Jabatan Notaris bertentangan dengan pasal 2 Peraturan Pemerintah Nomor 37 Tahun 1998 tentang Peraturan Jabatan Pejabat Pembuat Akta Tanah. Jenis penelitian yang digunakan adalah penelitian yuridis normatif dengan pendekatan perundang-undangan dan historis. Bahan-bahan hukum yang diperoleh dianalisis keterkaitannya satu sama lain, selain itu dalam pengolahan data digunakan pula interpretasi gramatikal. Hasil penelitian bahwa pembagian kewenangan notaris dan Pejabat Pembuat Akta Tanah (PPAT) yaitu bahwa kewenangan notaris berasal dari Peraturan Jabatan Notaris (Stb.1860 No.3), sedangkan dasar kewenangan Pejabat Pembuat Akta Tanah (PPAT) yaitu Peraturan Pemerintah Nomor 37 Tahun 1998 tentang Peraturan Jabatan Pejabat Pembuat Akta Tanah. Dan Pasal 15 ayat (2) huruf (f) Undang-Undang Nomor 2 Tahun 2014 tentang Jabatan Notaris tidak bertentangan dengan Pasal 2 Peraturan Pemerintah Nomor 37 Tahun 1998, karena akta-akta yang berkaitan dengan pertanahan yang menjadi kewenangan notaris adalah akta-akta yang bukan merupakan kewenangan dari Pejabat Pembuat Akta Tanah (PPAT), seperti akta sewa-menyewa, akta perjanjian jual beli, akta pelepasan hak atas tanah, kuasa untuk menjual, keterangan hak waris, wasiat, dan pemberian hak tanggungan.
\end{abstract}




\section{Kata Kunci: Notaris, Akta Yang Berkaitan Dengan Pertanahan, Pejabat Pembuat Akta Tanah.}

\section{Pendahuluan}

Perkembangan di bidang pertanah-an dewasa ini cukup menyita perhatian publik, dikarenakan tidak lagi dipan-dang sebagai hunian ataupun kegiatan usaha melainkan lebih dari itu dan dengan segala bentuk derivasinya, tanah mempunyai bermacam-macam aspek, mulai dari aspek ekonomi, aspek pertahanan, aspek keamanan, aspek sosial dan aspek budaya sehingga nuansa tarik ulur kepentingan sangat kental mengitarinya. Kasus demi kasus tentang pertanahan semakin meningkat signifikan, hal ini disebabkan karena kondisi masyarakat yang semakin sadar akan kepentingan dan haknya. Pendaftaran tanah merupakan rangkaian kegiatan yang dilakukan oleh pemerintah secara terus menerus, berkesinambungan dan teratur yang meliputi pengumpulan, pengolahan, pembukuan, penyajian serta pemeliharaan data fisik dan data yuridis. Melalui Peraturan Pemerintah Nomor 24 Tahun 1997 Tentang Pendaftaran Tanah
(Lembaran Negara Nomor 59 Tahun 1997, Tambahan Lembaran Negara Nomor 3696), dinyatakan bahwa pemerintah telah mewajibkan kepada seluruh pemegang hak atas tanah untuk mendaftarkan tanahnya kepada instansi yang berwenang, Hartono. 2014:.ix).

Perihal tersebut adalah untuk melaksanakan amanat UndangUndang Pokok Agraria (UUPA) Nomor 5 Tahun 1960 (Lembaran Negara Nomor 104 Tahun 1960 Tambahan Lembaran Negara Nomor 2043) Pasal 19 juncto Peraturan Pemerintah (PP) Nomor 24 Tahun 1997 guna menjamin adanya kepastian hukum hak atas tanah yang di miliki oleh subyek hukum.

Dalam proses pendaftaran tanah yang diselenggarakan oleh instansi pemerintah yaitu Badan Pertanahan Nasional, Kepala Kantor Pertanahan dibantu oleh Pejabat Pembuat Akta Tanah (PPAT) dan pejabat lain yang ditugaskan untuk melaksanakan kegiatan tertentu menurut Peraturan Pemerintah dan Peraturan perundang-undangan. Jual beli atas tanah harus dilakukan dengan suatu 
akta yang dibuat oleh dan dihadapan PPAT. Untuk menjamin kepastian dan ketertiban hukum dalam jual beli tanah, maka proses jual beli hanya dapat dilakukan di atas tanah yang dimiliki berdasarkan hak-hak atas tanah, artinya obyek tanah yang telah disahkan atau dibuktikan dengan bukti kepemilikan hak atas tanah yang diterbitkan oleh instansi yang berwenang

(Parlindungan, 1999:177). PPAT adalah pejabat umum yang diberi kewenangan untuk membuat akta-akta otentik mengenai perbuatan hukum tertentu mengenai hak atas tanah atau Hak Milik Atas Satuan Rumah Susun (Parlindungan, 1999:177). Adapun penjabarannya di dalam pasal 2 ayat 2 Peraturan Pemerintah Nomor 37 Tahun 1998 mengenai perbuatan hukum yang dilakukan oleh PPAT adalah sebagai berikut :

a. jual-beli,

b. tukar-menukar,

c. hibah,

d. pemasukan kedalam perusahaan (inbreng),

e. pembagian hak bersama,

f. pemberian Hak Guna Bangunan/Hak Pakai atas tanah Hak Milik,

g. pemberian Hak Tanggungan,

h. pemberian kuasa membebankan Hak Tanggungan (Parlindungan, 1999:180-181)
Kewenangan PPAT juga ditetapkan dalam Pasal 3 ayat 1 PP Nomor 37 Tahun 1998 yaitu membuat akta otentik mengenai semua perbuatan hukum sebagaimana dimaksud dalam pasal 2 ayat 2 mengenai hak atas tanah dan hak milik atas satuan rumah susun yang terletak didalam daerah kerjanya (Santoso, 2017:325). Jadi, PPAT hanya berwenang membuat 8 (delapan) macam akta yang ditetapkan dalam PP Nomor 37 Tahun 1998.

Lahirnya Undang-Undang Nomor 2 Tahun 2014 tentang Perubahan atas Undang-Undang Nomor 30 Tahun 2004 tentang Jabatan Notaris (Lembaran Negara Republik Indonesia Tahun 2014 Nomor 3, Tambahan Lembaran Negara Republik Indonesia Nomor 5491) (selanjutnya disebut UUJN) adalah aturan dasar bagi para notaris dalam melaksanakan jabatannya. Sebagaimana diketahui sebelum ditetapkannya UUJN, notaris menjalankan jabatannya berdasarkan Reglement op Het Notaris Ambt in Indonesie (Stbl. 1860:3) atau lebih dikenal dengan sebutan Peraturan Jabatan Notaris (PJN), sebagaimana 
telah diubah terakhir dalam

Lembaran Negara Tahun 1945

Nomor 101 Multazam,2014:148).

Dengan diun-dangkannya UUJN maka PJN dan peraturan pelaksananya yang disebut dalam pasal 91 UUJN dinyatakan tidak berlaku lagi.

Mengenai kewenangan notaris dalam pasal 15 ayat 1 UUJN adalah :

"Notaris berwenang membuat akta autentik mengenai semua perbuatan, perjanjian, dan penetapan yang diharuskan oleh peraturan perundang-undangan dan atau yang dikehendaki oleh yang berkepentingan untuk dinyatakan dalam akta autentik, menjamin kepastian tanggal pembuatan akta, menyimpan akta, memberikan grosse, salinan dan kutipan akta, semuanya itu sepanjang pembuatan akta itu tidak ditugaskan atau dikecualikan kepada pejabat lain atau orang lain yang ditetapkan oleh Undang-Undang." (Pasal 15 UU Nomor 2 Tahun 2014)

Selain kewenangan di atas, terdapat pula kewenangan lain yang tercantum didalam pasal 15 ayat 2 yaitu :

a. Mengesahkan tanda tangan dan menetapkan kepastian tanggal surat di bawah tangan dengan mendaftar dalam buku khusus,

b. Membukukan surat dibawah tangan dengan mendaftarkan kedalam buku khusus, c. Membuat kopi dari asli surat di bawah tangan berupa salinan yang memuat uraian sebagaimana ditulis dan digambarkan dalam surat yang bersangkutan,

d. Melakukan pengesahan kecocokan fotocopy dengan surat aslinya,

e. Memberikan penyuluhan hukum sehubungan dengan pembuatan akta,

f. Membuat akta yang berkaitan dengan pertanahan,

g. Membuat akta risalah lelang (Pasal 15 UU Nomor 2 Tahun 2014).

Akan tetapi dari beberapa kewenangan notaris tersebut yaitu dalam pasal 15 ayat 2 huruf (f) mengenai membuat akta berkaitan dengan pertanahanan, terancam tidak dapat berjalan dengan baik di lapangan (Thamrin, 2011:108), dikarenakan dalam hal ini terjadi kekaburan norma yang dimiliki oleh notaris perihal kewenangan notaris dalam membuat akta pertanahan. Kehadiran pasal 15 ayat 2 huruf (f) tersebut telah menimbulkan silang pendapat antara notaris dan PPAT yang sampai sekarang ini belum dapat diselesaikan sehingga dalam penelitian ini dirumuskan permasalahan sebagai berikut :1) Apakah Dasar Pembagian Kewenangan Notaris dan Pejabat Pembuat Akta Tanah (PPAT) di 
dalam Bidang Pertanahan; 2) Apakah pasal 15 ayat 2 huruf (f) UndangUndang Nomor 2 Tahun 2014 tentang Jabatan Notaris bertentangan dengan pasal 2 Peraturan Pemerintah Nomor 37 Tahun 1998 tentang Peraturan Jabatan Pejabat Pembuat Akta Tanah.

\section{Metode Penelitian}

Untuk mengkaji permasalahan diatas, maka jenis penelitian yang digunakan dalam penulisan tesis ini adalah penelitian yuridis normatif, dengan pendekatan perundangundangan, pendekatan konsep dan pendekatan historis. Kemudian bahan-bahan hukum yang diperoleh, dikumpulkan dan disusun secara sistematis, kemudian akan dianalisis dan dikaji keterkaitannya satu sama lain, selain itu dalam pengolahan data digunakan pula interpretasi gramatikal.

\section{Pembahasan}

Dasar Pembagian Kewenangan Notaris dan Pejabat Pembuat Akta Tanah (PPAT) Dalam Bidang Pertanahan

Jabatan Pejabat Pembuat Akta Tanah (PPAT) dikenal sejak berlakunya Peraturan Pemerintah
Nomor 10 Tahun 1961 tentang Pendaftaran Tanah sebagai peraturan pelaksana dari ketentuan pasal 19 Undang-undang Nomor 5 Tahun 1960 tentang Peraturan Dasar PokokPokok Agraria (UUPA) (Kusnadi,2010:20) yang menginstruksikan kepada pemerintah untuk menyelenggarakan pendaftaran tanah di seluruh wilayah republik Indonesia yang akan diatur dengan Peraturan Pemerintah. Melalui Peraturan Pemerintah (PP) Nomor 10 Tahun 1961 inilah mulai diatur mengenai peran Pejabat Pembuat Akta Tanah (PPAT) yang dirumuskan dalam pasal 19 PP Nomor 10 Tahun 1961, yang menegaskan bahwa setiap perjanjian yang bermaksud memindahkan hak atas tanah, memberikan suatu hak baru atas tanah, menggadaikan tanah atau meminjam uang dengan hak atas tanah sebagai tanggungan, harus dibuktikan dengan suatu akta yang dibuat oleh dan dihadapan Pejabat yang ditunjuk oleh Menteri Agraria.

Dalam PP Nomor 24 Tahun 1997 yang menyempurnakan PP Nomor 10 Tahun 1961, tetap dipertahankan tujuan dan sistem yang digunakan, yang pada 
hakikatnya sudah ditetapkan dalam UUPA yaitu bahwa pendaftaran tanah diselenggarakan dalam rangka memberi jaminan kepastian hukum dibidang pertanahan dan sistem publikasinya adalah negatif tetapi mengandung unsur positif. UUPA memang tidak menyebut secara tegas tentang Jabatan PPAT, namun penyebutan tentang adanya pejabat yang akan bertindak untuk membuat akta terhadap perbuatan hukum tertentu mengenai tanah, dinyatakan dalam Pasal 19 PP Nomor 10 Tahun 1961 sebagai peraturan pelaksana UUPA. Serangkaian ketentuan yang berkaitan satu sama lain tersebut sudah cukup untuk memberikan pemahaman, bahwa keberadaan Jabatan PPAT bersumber pada UUPA sehingga memiliki landasan hukum yang kuat. Sebagai pendukung hak dan kewajiban, maka jabatan itu dapat menjamin kesinambungan hak dan kewajiban, walaupun penjabatnya bergantiganti.

Untuk memperkuat status dan kedudukan PPAT kemudian diterbitkan Peraturan Jabatan Pejabat Pembuat Akta Tanah yang dituangkan dalam PP Nomor 37
Tahun 1998 tentang Peraturan Jabatan Pejabat Pembuat Akta Tanah (PJ PPAT), sebagai pelengkap dari PP Nomor 24 Tahun 1997 tentang Pendaftaran Tanah, yang menentukan bahwa PPAT adalah pejabat umum yang diberi kewenangan untuk membuat aktaakta otentik mengenai perbuatan hukum tertentu menyangkut hak atas tanah atau hak milik atas satuan rumah susun (pasal 1 Angka 1). Serta dibentuk pula Peraturan Menteri Negara Agraria/Kepala Badan Pertanahan Nasional (Permenag/ Kepala BPN) Nomor 4 Tahun 1999 tentang Ketentuan Pelaksanaan PP Nomor 37 Tahun 1998 tentang Peraturan Jabatan Pejabat Pembuat Akta Tanah. Pada tanggal 16 Mei 2006 Permenag/ Kepala BPN Nomor 4 Tahun 1999 tersebut dicabut dan diganti dengan Peraturan Kepala BPN Republik (RI) Indonesia Nomor 1 Tahun 2006 tentang Ketentuan Pelaksanaan Peraturan Pemerintah Nomor 37 Tahun 1998 Tentang Peraturan Jabatan Pejabat Pembuat Akta Tanah (PJ PPAT).

Beberapa pasal dalam Peraturan Kepala BPN RI Nomor 1 Tahun 2006 telah diubah dan pada tanggal 
26 Oktober 2009 ditetapkanlah Peraturan Kepala BPN RI Nomor 23

Tahun 2009 tentang Perubahan Peraturan Kepala BPN RI Nomor 1 Tahun 2006 tentang Ketentuan Pelaksanaan PP Nomor 37 Tahun 1998 tentang Peraturan Jabatan Pejabat Pembuat Akta Tanah. Jika dilihat dasar pembentukan PP Nomor 37 Tahun 1998, bersumber pada pasal 7 ayat (3) PP Nomor 24 Tahun 1997, yang berinduk pada UUPA (UUPA). Pada konsideran menimbang huruf "b" PP Nomor 37 Tahun 1998 tersebut secara tegas dinyatakan bahwa pertimbangan pembentukan PP tersebut yaitu dalam rangka pelaksanaan pendaftaran tanah, dengan menetapkan jabatan PPAT yang diberi kewenangan untuk membuat alat bukti mengenai perbuatan hukum tertentu mengenai hak atas tanah dan Hak Milik atas Satuan Rumah Susun yang akan dijadikan dasar pendaftaran.

Di samping itu, kewenangan PPAT juga diatur didalam PP Nomor 37 Tahun 1998 tentang Peraturan Jabatan Pejabat Pembuat Akta Tanah, yaitu :
1) Pasal 1 angka (4) UndangUndang Nomor 4 Tahun 1996 tentang Hak Tanggungan (Lembaran Negara Republik Indonesia Tahun 1996 Nomor 42), menyatakan bahwa :

"Pejabat Pembuat Akta Tanah, yang selanjutnya disebut PPAT adalah pejabat umum yang diberi wewenang untuk membuat akta pemindahan hak atas tanah, akta pembebanan hak atas tanah, dan akta pemberian kuasa membebankan Hak Tanggungan menurut peraturan perundang-undangan yang berlaku." (Agustiwi,2014:6)

2) Pasal 14 ayat (1) UndangUndang Nomor 16 Tahun 1985 (Lembaran Negara Republik Indonesia Tahun 1985 Nomor 75) tentang Rumah Susun, manyatakan bahwa :

"Pemberian Hipotik sebagaimana dimaksud dalam pasal 12 dan pasal 13 dilakukan dengan akta Pejabat Pembuat Akta Tanah dan wajib didaftarkan pada Kantor Agraria Kabupaten dan Kota-madya untuk dicatat pada buku tanah dan sertipikat hak yang bersangkutan."

3) Pasal 24 ayat (1) UndangUndang Nomor 21 Tahun 1997 (Lembaran Negara Republik Indonesia Tahun 1997 Nomor 44) tentang Bea Perolehan Hak 
Atas Tanah dan Bangunan, menyatakan bahwa :

"Pejabat Pembuat Akta Tanah/

Notaris hanya dapat menan-

datangani akta pemindahan hak atas tanah dan atau bangunan setelah wajib pajak menyerahkan bukti pembayaran pajak."

Dapat diketahui bahwa pemasukan pasal tentang PPAT dalam Undang-Undang Hak Tanggungan adalah sebagai sarana untuk mencegah terjadinya polemik, karena jika PPAT tidak diatur atau disebut dalam Undang-Undang Hak Tanggungan ini, maka secara otomatis PPAT hanya diatur dalam PP, sehingga ketika UUJN disahkan dan terdapat pasal yang berkaitan dengan kewenangan notaris dalam membuat akta yang berkaitan dengan pertanahan, maka kewenangan PPAT akan menjadi gugur karena kewenangan ini hanya akan menjadi kewenangan notaris sesuai dengan asas lex superior derogate lex inferior, dimana peraturan yang lebih tinggi mengesampingkan peraturan yang lebih rendah tingkatannya apabila saling bertentangan, adapun hierarki peraturan perundang- undangan dapat dilihat pada pasal 7 UU Nomor 12 Tahun 2011 (Lembaran Negara Republik Indonesia Tahun 2011 Nomor 82), tentang Pembentukan Peraturan Perundang-Undangan.

Dalam kaitannya dengan eksistensi PPAT, dengan mengacu pendapat Philipus M. Hadjon maka berarti sumber kewenangannya tidak didasarkan pada sumber yang sah, artinya bukan didasarkan pada undang-undang sebagaimana yang ditentukan dalam UUJN. Disamping itu pengang-katannya juga tidak dilakukan oleh Kepala Negara seperti yang terjadi pada notaris. Seyogyanya sebagai pejabat umum, pengangkatannya dilakukan oleh Kepala Negara, bukan oleh Menteri seperti yang terjadi pada jabatan PPAT.

Lembaga PPAT berada dan diciptakan oleh Negara atau oleh pemerintah sebagai implementasi dari policyrules dari Negara atau pemerintah, artinya PPAT ini merupakan suatu lembaga yang sengaja dibuat atau diciptakan oleh Negara atau pemerintah sebagai salah satu upaya bentuk pelayanan Negara atau pemerintah terhadap 
rakyatnya. Hal ini sama dengan notaris. Namun PPAT hanya diatur didalam PP Nomor 37 Tahun 1998 yang dianggap masih belum memadai untuk tugas dan peranan PPAT. Penetapan PP Nomor 37 Tahun 1998 oleh pemerintah dianggap perlu untuk mengisi kekosongan hukum. Hal tersebut dapat dimaklumi, karena dalam teori hukum ada pendapat bahwa apabila ada kebutuhan untuk mengatasi keko-songan hukum, kepala pemerintahan berwenang menetapkan peraturan yang dibutuhkan untuk kepentingan umum.

\section{Kesesuaian Pasal 15 Ayat 2 Huruf} (f) Undang-Undang Nomor 2 Tahun 2014 tentang Jabatan Notaris dengan Pasal 2 Peraturan Pemerintah Nomor 37 Tahun 1998

Secara teori, tanah mempunyai nilai ekonomis sehingga dapat dilihat pentingnya arti tanah bagi kehidupan masyarakat. Tanah sangat erat sekali hubungannya dengan kehidupan manusia, karena manusia membutuhkan tanah selain untuk tempat tinggal juga untuk perkebunan, pertanian, peternakan, jalan serta kebutuhan lainnya. Tanah tidak hanya dimaksudkan sebagai permukaan bumi atau lapisan bumi paling atas, tetapi meliputi ruang di atas dan dibawah permukaan bumi dan setiap benda yang tumbuh di atas dan/atau yang melekat secara permanen di atas permukaan bumi, termasuk pula yang berkaitan dengan kepemilikan tanahnya. (Setiawan,2009:161).

Karena pentingnya tersebut, maka untuk mengatur kehidupan manusia terutama dalam hal tanah diperlukan suatu pendaftaran tanah. Di Indonesia, tentang pendaftaran tanah diatur dalam UUPA. Pendaftaran tanah merupakan awal dari proses lahirnya sebuah bukti pemilikan atas tanah, dimaksudkan untuk menjamin kepastian hukum bagi pemiliknya, sebagaimana diamanatkan oleh undang-undang.

Sebagaimana peraturan pelaksanaan dari Pasal 19 UUPA tentang perlunya pendaftaran tanah untuk kepastian hukum, maka dibentuklah PP Nomor 24 Tahun 1997 tentang Pendaftaran Tanah. Pada proses pendaftaran tanah ini kemudian diperlukan suatu alat bukti yang memberikan kejelasan tentang hak dan kewajiban seseorang sebagai subyek hukum. Akta autentik sebagai alat bukti yang terkuat dan terpenuh 
mempunyai peranan penting, melalui akta autentik ini ditentukan secara jelas hak dan kewajiban, menjamin kepastian hukum dan juga diharapkan untuk menghindari adanya sengketa.

Terkait dengan obyek pendaftaran tanah maka diperlukan suatu akta dalam memperoleh hak atas tanah tersebut yaitu akta-akta yang berkaitan dengan pertanahan. Jika melihat pada Undang-Undang Nomor 30 Tahun 2004 juncto Undang-Undang Nomor 2 Tahun 2014 tentang Jabatan Notaris, terutama pada pasal 15 ayat (2) huruf (f), maka selain PPAT, notaris juga berhak untuk membuat akta-akta yang berkaitan dengan pertanahan terhadap hak atas tanah seperti jual beli, tukar menukar, hibah, pembagian hak bersama dan seterusnya yang berkaitan dengan pertanahan. Namun dalam kenyataannya notaris tidak diperkenankan membuat akta pertanahan kalau belum lulus ujian yang dilakukan Departemen Kehakiman mengenai ujian untuk diangkat menjadi PPAT (Supriadi,2012:171). Terhadap ketentuan Pasal 15 ayat (2) huruf (f) Undang-undang Nomor 2
Tahun 2014 ini tidak memberikan penjelasan yang tersurat ataupun tersirat mengenai apa maksud dari membuat akta yang berkaitan dengan pertanahan dan ruang lingkup apa sajakah yang termasuk dalam akta yang berkaitan dengan pertanahan itu.

Pembuatan akta autentik diharuskan oleh peraturan perundangundangan dalam rangka menciptakan kepastian, ketertiban, dan perlindungan hukum. Adapun pejabat umum lain yang juga membuat akta autentik yang diharuskan oleh peraturan perundang-undangan yang dimaksud adalah PPAT yang diatur dalam PP Nomor 37 Tahun 1998 dan Pasal 1 angka (4) Undang-undang Nomor 4 Tahun 1996 tentang Hak Tanggungan Atas Tanah Beserta Benda-Benda yang Berkaitan Dengan Tanah.Mengenai pembuatan akta-akta yang berkaitan dengan pertanahan sampai saat ini masih menjadi tugas dari PPAT, sebagaimana disebutkan dalam PP Nomor 37 Tahun 1998 tentang PJ PPAT, yang tercantum di dalam pasal 2 ayat (1) bahwa PPAT bertugas membuat akta sebagai bukti telah dilakukannya perbuatan hukum 
tertentu mengenai hak milik atas satuan rumah susun dan hak atas tanah sebagai dasar bagi pendaftaran perubahan data pendaftaran tanah. Didalam pasal 2 ayat (2) PP Nomor 37 Tahun 1998 juncto Pasal 95 ayat (2) Peraturan Menag/Kepala BPN Nomor 3 Tahun 1997 jis pasal 2 ayat (2) Peraturan Kepala BPN RI Nomor 1 Tahun 2006 menetapkan bahwa perbuatan hukum mengenai hak atas tanah atau hak milik atas satuan rumah susun yang dibuktikan dengan PPAT, yaitu :

1) jual-beli,

2) tukar-menukar,

3) hibah,

4) pemasukan kedalam perusahaan (inbreng),

5) pembagian hak bersama,

6) pemberian Hak Guna Bangunan/Hak Pakai atas tanah Hak Milik,

7) pemberian Hak Tanggungan,

8) pemberian kuasa membebankan Hak Tanggungan.

Kewenangan PPAT ditetapkan dalam Pasal 3 ayat 1 PP Nomor 37 Tahun 1998 yaitu membuat akta otentik mengenai semua perbuatan hukum sebagaimana dimaksud dalam pasal 2 ayat 2 mengenai hak atas tanah dan hak milik atas satuan rumah susun yang terletak didalam daerah kerjanya (Santoso, 2017:325). Jadi, PPAT hanya berwenang membuat 8 (delapan) macam akta yang ditetapkan dalam PP Nomor 37 Tahun 1998 , Permenag /Kepala BPN RI Nomor 1 Tahun 2006, dan Peraturan Kepala BPN RI Nomor 8 Tahun 2012, yaitu akta jual beli, akta tukar-menukar, akta pemasukan kedalam perusahaan, akta pembagian hak bersama, akta pemberian hak tanggungan, akta pemberian hak guna bangunan atas tanah hak milik dan akta pemberian hak pakai atas tanah hak milik. Di luar 8 (delapan) macam akta tersebut, PPAT tidak berwenang membuat aktanya.

Kehadiran UUJN Nomor 2 Tahun 2014 juncto UU Nomor 30 Tahun 2004 bertentangan dengan tiga undang-undang di bidang pertanahan. Ketiga undang-undang yang ditabrak oleh UUJN yaitu UUPA, UU Nomor 16 Tahun 1985 tentang Rumah Susun, dan UU Nomor 4 Tahun 1996 tentang Hak Tanggungan (Purwaningsih, 2011:331). Ketentuan UUJN yang bertentangan dengan tiga Undangundang di bidang pertanahan adalah pasal 15 ayat (2) huruf (f) yang mengatur kewenangan notaris untuk membuat akta yang berkaitan dengan pertanahan.Pasal 15 ayat (2) huruf (f) 
tidak mengahapus eksistensi dan peran PPAT dalam tugas dan wewenangnya untuk permbuatan akta tanah.

Didalam hal ini akan digunakan teori kepastian hukum sebagai pisau analisis dalam membahas permasalahan terkait pasal 15 ayat 2 huruf (f) UUJN. Dalam pasal 15 ayat (2) huruf (f) UUJN merupakan bentuk bahasa hukum yang ambigu, hal ini disebabkan karena ketika UUJN disahkan mengandung polemik dan perdebatan tentang makna dari pasal tersebut, meski dalam pasal 15 ayat (1) sendiri disebutkan "bahwa sepanjang pembuatan akta tersebut tidak juga ditugaskan atau dikecualikan kepada pejabat lain atau orang lain yang ditetapkan oleh undang-undang", karena dalam pelaksanaannya terdapat akta-akta yang berkaitan dengan pertanahan yang tidak dapat atau pejabat yang ditugaskan untuk membuatnya tidaklah berwenang.

Sebagai contoh akta Perjanjian Pengikatan Jual Beli (PPJB) terhadap hak atas tanah, jika merujuk pada kewenangan PPAT pasal 2 PP Nomor 37 Tahun 1998, maka PPAT tidak berwenang membuat akta tersebut, dan begitu pula sebaliknya ketika notaris membuat Akta Jual Beli (AJB) yang merupakan kewenangan PPAT, maka berdasarkan PP Nomor 24 Tahun 1997, jika akta tersebut dijadikan dasar untuk pendaftaran tanah tentu tidak akan diterima oleh kantor pertanahan, karena dalam pasal 6 ayat (2) PP Nomor 24 Tahun 1997 dijelaskan bahwa dalam melaksanakan pendaf-taran tanah, Kepala Kantor Pertanahan dibantu oleh PPAT. Sejak berlakunya PP Nomor 10 Tahun 1961 tentang Pendaftaran Tanah, Jual Beli dilakukan oleh para pihak di hadapan PPAT yang sifatnya tunai, riil dan terang.

Didalam hukum adat, yang maksud dengan sifat tunai berarti bahwa penyerahan hak dan pembayaran harganya dilakukan pada saat yang sama. Sifat riil berarti bahwa dengan mengucapkan katakata dengan mulut saja belumlah terjadi jual beli. Jual beli dianggap telah terjadi dengan penulisan kontrak jual beli di muka Kepala Kampung atau PPAT serta penerimaan harga oleh penjual, meskipun tanah yang bersangkutan 
masih berada dalam penguasaan penjual. Sifat terang dipenuhi pada umumnya pada saat dilakukannya jual beli itu disaksikan oleh Kepala Desa, karena Kepala Desa dianggap orang yang mengetahui hukum dan kehadiran Kepala Desa mewakili warga masyarakat desa tersebut. Sekarang sifat terang berarti jual beli itu dilakukan menurut peraturan tertulis yang berlaku.

Dalam peraturan perundangundangan yang dipergunakan adalah bahasa hukum, bahasa dalam produk perundang-undangan sebagai bahasa hukum berada dalam lingkup kajian metabahasa, metabahasa sendiri adalah kajian bahasa sebagai produk pemikiran yang tidak terbatas kepada bahasa saja tetapi melibatkan ilmu lain (2014:144). Oleh karena itu, di dalam praktik hukum kalimatkalimatnya kebanyakan harus ditafsirkan terlebih dahulu. Metode interpretasi atau penafsiran hukum dilakukan dalam hal peraturannya ada, tetapi tidak jelas untuk dapat diterapkan pada peristiwa konkret. Interpretasi terhadap teks peraturannya pun masih tetap berpegang pada bunyi teks itu (Hamidi,2011:93). Bahasa hukum tidak boleh ambigu, karena jika terjadi keambiguan bahasa, maka akan terjadi ketidakpastian hukum (Hamidi,2011: 62). Dalam pasal 15 ayat (2) huruf (f) UUJN, merupakan bentuk bahasa hukum yang ambigu, hal ini disebabkan karena ketika UUJN disahkan mengandung polemik dan perdebatan tentang makna dari pasal tersebut, meski dalam pasal 15 ayat (1) sendiri disebutkan "bahwa sepanjang pembuatan akta tersebut tidak juga ditugaskan atau dikecualikan kepada pejabat lain atau orang lain yang ditetapkan oleh undang-undang", karena dalam pelaksanaannya terdapat akta-akta yang berkaitan dengan pertanahan yang tidak dapat atau pejabat yang ditugaskan untuk membuatnya tidaklah berwenang.

Sebagai contoh akta Perjanjian Pengikatan Jual Beli (PPJB) terhadap hak atas tanah, jika merujuk pada kewenangan PPAT pasal 2 PP Nomor 37 Tahun 1998, maka PPAT tidak berwenang membuat akta tersebut, dan begitu pula sebaliknya ketika notaris membuat Akta Jual Beli (AJB) yang merupakan kewenangan PPAT, maka berdasarkan PP Nomor 24 Tahun 
1997, jika akta tersebut dijadikan dasar untuk pendaftaran tanah tentu tidak akan diterima oleh kantor pertanahan, karena dalam pasal 6 ayat (2) PP Nomor 24 Tahun 1997 dijelaskan bahwa dalam melaksanakan pendaftaran tanah Kepala Kantor Pertanahan dibantu oleh PPAT. Sejak berlakunya PP Nomor 10 Tahun 1961 tentang Pendaftaran Tanah, Jual Beli dilakukan oleh para pihak di hadapan PPAT yang sifatnya tunai, riil dan terang.

Contoh lain dari kewenangan notaris yang berkaitan dengan pertanahan yang menjadi kabur dalam pembuatan akta adalah akta yang berkaitan dengan pertanahan yang dapat dibuat oleh notaris dan juga PPAT yaitu akta Surat Kuasa Membebankan Hak Tanggungan (SKMHT). Berdasarkan pasal 15 ayat (1) UU Nomor 4 Tahun 1996 tentang Hak Tanggungan (Lembaran Negara Republik Indonesia Tahun 1996 Nomor 42), SKMHT wajib dibuat dengan akta notaris atau akta PPAT, dengan syarat :

a) Tidak memuat kuasa untuk melakukan perbuatan hukum lain daripada membebankan Hak Tanggungan;

b) Tidak memuat kuasa substitusi;

c) Mencantumkan secara jelas obyek Hak Tanggungan, jumlah utang dan nama serta identitas kreditornya, nama dan identitas debitor apabila debitor bukan pemberi Hak Tanggungan.

Pada syarat tersebut tidak terdapat bahwa akta SKMHT yang dibuat oleh notaris bentuknya haruslah sesuai dengan akta PPAT yang dikeluarkan oleh BPN.Tetapi mengenai SKMHT yang dibuat oleh notaris ada Kantor Pertanahan yang meminta dibuat dengan blanko akta yang dicetak pemerintah namun ada juga Kantor Pertanahan yang meminta dibuat oleh notaris dengan kertas biasa yang isinya mencontoh blanko akta. Hal ini juga menimbulkan perdebatan yang lain tentang makna akta otentik sendiri, karena salah satu syarat suatu akta disebut otentik adalah bentuknya yang ditentukan oleh undangundang, dan jika mengacu pada UUJN maka akta SKMHT harus dibuat berdasarkan Pasal 38 UUJN itu sendiri. 
Dari uraian tersebut, maka pasal 15 ayat (2) huruf (f) dapatlah dikatakan mempunyai pengertian yang kabur sebagaimana dikatakan oleh JJ. H. Bruggink bahwa tentang sebuah pengertian yang kabur itu memiliki inti yang kurang jelas, yang lingkupnya dapat ditentukan secara persis, tetapi bahwa di sekelilingnya terdapat batas yang tidak jelas yang lingkupannya tidak dapat ditetapkan secara persis (Bruggink,2011:61). Hukum harus dilaksanakan dengan pasti, oleh karena itu hukum harus jelas.Dengan kepastian hukum, masyarakat dan penegak hukum dapat berpedoman pada hukum tersebut.Untuk menjadi jelas, setiap istilah dalam hukum harus dirumuskan secara terang dan tegas sehingga tidak ada keragu-raguan dalam memahami maksud dari istilah tersebut. Kepastian hukum menuntut agar ada prosedur pembuatan dan peresmian hukum yang jelas dan dapat diketahui umum (Masyur, 2016:47).

Didalam kaitan ini akan digunakan teori kepastian hukum yang menyatakan bahwa kepastian hukum secara normatif adalah ketika suatu peraturan dibuat dan diundangkan secara pasti karena mengatur secara jelas dan logis. Jelas dalam hal ini berarti tidak terdapat kekaburan norma atau keraguan dan logis dalam artian ia menjadi satu sistem norma dengan norma lain sehingga tidak berbenturan atau menimbulkan konflik norma. Karena jika dilihat dalam pasal 15 ayat (2) huruf (f) UUJN dimana pasal tersebut menyatakan bahwa notaris mempunyai kewenangan membuat akta di bidang pertanahan, namun di penjelasan Undang-Undang tersebut hanya dinyatakan cukup jelas, yang pada akhirnya menimbulkan banyak penafsiran terhadap pasal tersebut, karena yang berwenang membuat akta di bidang pertanahan adalah PPAT yang diatur dalam PP Nomor 37 Tahun 1998 tentang Peraturan Jabatan Pembuat Akta Tanah. Notaris dan PPAT dalam menjalankan tugas jabatannya wajib berpedoman secara normatif kepada aturan hukum yang terkait dengan segala tindakan yang akan diambil untuk kemudian dituangkan dalam akta.

Teori menurut Jan M. Otto yang dikutip oleh Sidaharta yaitu bahwa kepastian hukum dalam situasi 
tertentu mensyaratkan sebagai berikut (Gautama, 2006: 85):

1) Adanya berbagai aturan hukum yang dapat dimaknai dengan jelas, konsisten, dan mudah diperoleh, yang diterbitkan oleh kekuasaan Negara;

2) Bahwa semua instansi pemerintahan menerapkan dan menjalankan semua aturan hukum tersebut secara konsisten dan juga tunduk dan taat kepadanya.

Berdasarkan ketentuan tersebut, maka pasal 15 ayat (2) huruf (f) dalam UUJN ini tidak atau bisa dikatakan belum memberikan kepastian hukum, pasal ini memberikan kekaburan makna mengenai akta yang berkaitan dengan pertanahan karena di satu sisi yang berwenang adalah PPAT untuk membuatnya, akan tetapi disisi lain notaris juga berwenang untuk membuatnya meskipun bukan aktaakta yang menjadi wewenang PPAT, tetapi tetap berkaitan dengan pertanahan dan juga dijadikan dasar untuk pendaftaran tanah.

Untuk memaknai Pasal 15 ayat (2) huruf (f) UUJN agar tidak memiliki kekaburan makna jika ditinjau dari teori kepastian hukum, maka harus dengan memahami teks otoritatif dalam pasal tersebut serta melihat keberlakuan kaidah hukum. Untuk dapat menghimpun dan mensiste-matisasi, maka teks otoritatif itu harus dipahami, memahami teks berarti mengetahui makna dari teks itu, dan pengetahuan tersebut diperoleh dengan menginterpretasi teks yang bersangkutan (Sidharta,2009:161). Selanjutnya B. Arief Sidharta mengemukakan menginterpretasi teks otoritatif berarti mendistilasi kaidah hukum dari dalam teks itu serta sekaligus menentukan makna, artinya jangkauan wilayah keberlakuan kaidah hukum tersebut, karena itu interpretasi sesungguhnya selalu mengarah pada kejadian konkret.

Dalam Pasal 15 ayat (2) huruf (f) UUJN agar tidak menjadi kabur maknanya, maka teks otoritatif dari pasal tersebut harus diinterpretasikan dengan mendistilasi kaidah hukum dalam teks pasal tersebut dengan melihat jangkauan wilayah keberlakuan kaidah hukum tersebut dengan mengarah pada kejadian konkret. Untuk melihat jangkauan wilayah keberlakuan kaidah hukum 
dalam Pasal 15 ayat (2) haruf (f) UUJN dapat dilihat pendapat JJ. H. Bruggink tentang tiga bentuk keberlakuan (Bruggink, 2011: 149):

1) Keberlakuan Faktual Kaidah Hukum

Keberlakuan faktual ini berkenaan dengan efektivitas, artinya kaidah hukum berlaku secara faktual jika para warga masyarakat, untuk siapa kaidah hukum itu berlaku mematuhi kaidah hukum tersebut, dalam kaitannya dengan Pasal 15 ayat (2) huruf (f) UUJN ini, bahwa masyarakat dalam membuat akta yang berkaitan dengan pertanahan akan meminta bantuan kepada notaris sepanjang akta tersebut tidak menjadi kewenangan PPAT.

2) Keberlakuan Normatif atau Formal Kaidah Hukum

Keberlakuan normatif ini dibentuk sesuai aturan-aturan hukum yang berlaku oleh badan yang berwenang dan bahwa dalam aspek ini secara subtansial tidak bertentangan dengan kaidah-kaidah hukum lainnya terutama yang lebih tinggi tingkatannya. Dalam UUJN Pasal 15 ayat (2) huruf (f) terkait kewenangan notaris dalam membuat akta di bidang pertanahan ini pada prosesnya dibentuk sesuai dengan aturan yang berlaku, akan tetapi tidak semua akta yang berkaitan dengan pertanahan yang bisa dibuat oleh notaris terutama akta-akta yang menjadi kewenangan PPAT.

3) Keberlakuan Evaluatif Kaidah Hukum

Keberlakuan evaluatif ini dapat diartikan pada dapat diterimanya kaidah hukum, artinya Pasal 15 ayat (2) huruf (f) UUJN ini dapat diterima dalam masyarakat bahwa untuk aktaakta yang berkaitan dengan pertanahan sepanjang tidak ditugaskan pada pejabat lain dalam hal ini PPAT, maka notaris berwenang untuk membuatnya.

Oleh karena itu makna kewenangan notaris dalam membuat akta yang berkaitan dengan pertanahan sampai saat ini selama antara jabatan PPAT dan notaris masih berdiri sendiri-sendiri, maka kewenangan yang dimiliki notaris ini merupakan kewenangan yang sempit, artinya notaris dapat membuat akta pertanahan selama akta itu tidak juga menjadi kewenangan PPAT, seperti Akta Sewa-Menyewa, Akta Perjanjian Jual Beli, Akta Pelepasan Hak Atas 
Tanah, Kuasa Untuk Menjual, Keterangan Hak Waris, Wasiat, dan Pemberian Hak Tanggungan.

\section{Simpulan}

Berdasarkan pembahasan yang dilakukan maka dapat diperoleh kesimpulan sebagai berikut:

1) Notaris didalam menjelankan jabatannya memperoleh kewenangan secara atribusi, yang diatur didalam Undang-Undang Nomor 2 Tahun 2014 tentang Jabatan Notaris. Sedangkan PPAT memperoleh kewenangan tidak didasarkan pada UndangUndang. PPAT dibentuk oleh negara atau pemerintah sebagai salah satu upaya pelayanan negara atau pemerintah kepada rakyatnya. Yang hanya diatur di dalam Peraturan Pemerintah Nomor 37 Tahun 1998.

2) Pasal 15 ayat (2) huruf (f) Undang-Undang Nomor 2 Tahun 2014 tentang Jabatan Notaris tidak bertentangan dengan Pasal 2 Peraturan Pemerintah Nomor 37 Tahun 1998 tentang Peraturan Jabatan Pejabat Pembuat Akta Tanah (PPAT) karena akta-akta yang berkaitan dengan pertanahan yang menjadi kewenangan notaris adalah akta-akta yang bukan merupakan kewenangan dari Pejabat Pembuat Akta Tanah (PPAT) seperti Akta Sewa-Menyewa, Akta Perjanjian Jual Beli, Akta Pelepasan Hak Atas Tanah, Kuasa Untuk Menjual, Keterangan Hak Waris, Wasiat, dan Pemberian Hak Tanggungan.

\section{Daftar Pustaka}

\section{Buku}

Burggink, JJ. H. (2011) Alih Bahasa B. Arief Sidharta, Refeksi Tentang Hukum. Bandung: Citra Aditya Bakti

Gautama, Sidharta. (2006) Kepastian Hukum Indonesia.Bandung: Penerbit Cahaya

Hamidi, Jazim. (2011) Butir-Butir Pemikiran Dalam Hukum, Mengenal Lebih Dekat Hermeneutika Hukum. Bandung: Refika Aditama

Harsono, Boedi. (1997) Perkembangan Hukum Tanah Adat Melalui Yurisprudensi. Ceramah disampaikan pada Simposium Undang-Undang Pokok Agraria dan Kedudukan Tanah-Tanah Adat Dewasa ini, Banjarmasin, 7 Oktober

Hartini, Lilis. (2014) Bahasa \& Produk Hukum. Bandung: Refika Aditama 
Hartono, J. Andy. (2014) Hukum Pertanahan : Karakterisrik Jual Beli Tanah yang Belum Terdaftar Hak Atas Tanahnya. Cetakan Kedua. Surabaya: Laksbang Justita

Kusnadi, Adi. (2010) Masalah Hukum Jabatan Notaris Dalam Kegiatan Pertanahan. Jakarta: Badan Pembinaan Hukum Nasional Kementerian Hukum dan Hak Asasi Manusia RI

Kelsen, Hans. (2014) Teori Umum Tentang Hukum dan Negara.Bandung: Nusa Media

M. Hadjon, Philipus. (2005) Pengantar Hukum Administrasi Negara (Introduction To The Indonesian Administrative Law). Yogyakarta: Gajah Mada University Presss

Parlindungan, A.P. (1999) Pendaftaran Tanah Di Indonesia. Bandung: Mandar Maju

Setiawan, Yudhi. (2009) Instrumen Hukum Campuran (gemeenschapelijkrecht) Dalam Konsolidasi Tanah. Jakarta: Raja Grafindo Persada

Sidharta, Bernard Arief. (2009) Refleksi Tentang Struktur Ilmu Hukum. Bandung: Mandar Maju

Supriadi. (2012) Hukum Agraria. Jakarta: Sinar Grafika
Thamrin, Husni. (2011) Pembuatan Akta Pertanahan Oleh Notaris. Yogyakarta: Laksbang Pressindo

Tobing, G.H.S Lumban. (1991) Peraturan Jabatan Notaris. Jakarta: Gelora Aksara Pratama

\section{Peraturan Perundang-undangan}

Undang-Undang Republik Indonesia Nomor 2 Tahun 2014 tentang Perubahan atas UndangUndang Nomor 30 Tahun 2004 tentang Jabatan Notaris

\section{Jurnal}

Agustiwi, Asri. "Kajian Terhadap Peran Pejabat Pembuat Akta Tanah menurut Peraturan Pemerintah Nomor 24 Tahun 1997 tentang Pendaftaran Tanah". Rechtstaat Ilmu Hukum Vol. 8, No. 2, (Oktober 2014): 6. diakses 1 April 2017. doi :http://www.unsa.ac.id/ejourn al/index.php/rechstaat/article/ view/1

Masyur, M. Hamidi. "Lembaga Eksaminasi Pertanahan Sebagai Alternatif Model Penyelesaian Sengketa di Bidang Pertanahan".Adhaper Vol. 2, No. 1 (Januari-Juni 2016):47. diakses tanggal 2 April 2017.doi :http://www.jhaper.org/index. php/JHAPER/article/view/23

Multazam, Mochammad Tanzil. “ Kewenangan Notaris Sebagai Pejabat Umum dalam Membuat Akta Pertanahan dan Akta Risalah Lelang Menurut Undang-Undang 
Nomor 30 Tahun 2004 tentang Jabatan Notaris". Rechtsidee Vol. 1, No. 2, ( Juni 2014): 148. diakses 05 Januari $2017 . \quad$ doi :http://ojs.umsida.ac.id/index. php/rechtsidee

Purwaningsih, Endang. "Penegakan Hukum Jabatan Notaris dalam Pembuatan Perjanjian Berdasarkan Pancasila dalam Rangka Kepastian Hukum".Adil: Jurnal Hukum Vol. 2, No. 3, (3 Desember 2011):331. diakses 1 April 2017.doi:

http://portal.kopertis3.or.id/ha ndle/123456789/1422

Santoso, Urip. "Pelepasan Hak Atas Tanah Untuk Kepentingan Perusahaan Swasta".Perspektif Vol. XV, No. 3, (Juli 2010): 325. diakses 2 April 2017.doi :http://jurnalperspektif.org/index.php/pers pektif/article/view/58/50 